\title{
Membangun Jiwa Enterpreneurship Santri Melalui Pengembangan Usaha Ekonomi Kreatif
}

\author{
Zuanita Adriyani, M. Azmi Ahsan, Retno Ayu Wulandari \\ Universitas Islam Negeri Walisongo Semarang \\ Email : zuanita.adriyani@walisongo.ac.id
}

\begin{abstract}
According to the demand of the times, islamic boarding should be able to graduate with various skill because not all of the output or graduates will become a scholar or kyai. One of the education that become the provision for students of Raudlotul Qur'an Islamic Boarding School is entrepreneurship. Entrepreneurship experience gained when in boarding school will be one of the way for graduates to get job prospects that will be able to generate money purse coffers. In this technological era, creative economy is needed in improving the entrepreneurship spirit to develop ideas that will create an innovation. The spirit of entrepreneurship of Islamic boarding school students of Raudlotul Qur'an will grow with critical thinking, responsive state and creative if there is assistance from people who are more competent. Problems related to the waste of any existing business field will be an additional value after proper processing. After the implementation of creative economic business assistance, the students of raudlatul quran islamic boarding manager of each business field able to process wastes every business sector and increase revenue.
\end{abstract}

Abstrak: Sesuai tuntutan zaman, pesantren harus mampu mencetak lulusan dengan berbagai keterampilan karena tidak semua output atau alumni menjadi seorang ulama atau kyai. Salah satu pendidikan yang menjadi bekal bagi santri Pondok Pesantren Raudlotul Qur'an adalah berwirausaha. Pengalaman berwirausaha yang diperoleh ketika di pesantren akan menjadi salah satu jembatan bagi lulusan untuk mendapatkan prospek pekerjaan yang nantinya dapat menghasilkan pundi pundi uang. Dalam era serba tekhnologi ini, ekonomi kreatif sangat diperlukan dalam meningkatkan jiwa entrepreneurship untuk mengembangkan ide maupun gagasan yang nantinya akan menciptakan suatu inovasi. Jiwa entrepreneurship santri pondok pesantren Raudlotul Qur'an akan berkembang disertai pemikiran yang kritis, tanggap keadaan dan kreatif jika ada pendampingan dari orang-orang yang lebih berkompeten. Permasalahan terkait limbah-limbah dari setiap bidang usaha yang ada akan menjadi nilai tambahan setelah dilakukan pengolahan dengan tepat. Setelah dilaksanakan pendampingan usaha ekonomi kreatif, santri-santri pengelola setiap bidang usaha mampu mengolah limbah-limbah setiap sektor usaha dan menambah pendapatan.

Kata Kunci: wirausaha, santri, bisnis ekonomi kreatif. 


\section{PENDAHULUAN}

Pondok pesantren memiliki peran besar dalam upaya mencerdaskan kehidupan bangsa. Kiprah pesantren dalam pembangunan bangsa dimulai sejak pra kemerdekaan sampai saat ini. Bahkan, sebagai lembaga pemberdayaan masyarakat, pesantren telah berperan besar sebagai agen pembaruan sosial seperti transmigrasi, keluarga berencana dan gerakan akan sadar lingkungan (Imron: 2017). Pondok pesantren merupakan lembaga pendidikan islam yang terdiri dari kiyai, ustadz, santri yang mempelajari, memahami, mendalami, menghayati dan mengamalkan ajaran islam dengan menekankan pentingnya moral keagamaan sebagai pedoman perilaku sehari-hari.

Pondok pesantren erat kaitannya dengan rutinitas kegiatan keagamaan yang cukup padat dari pagi hingga malam.Bahkan ada beberapa pondok pesantren yang melarang para santrinya untuk berinteraksi dengan dunia luar.Harapan dari pengelola pondok adalah agar para santri bisa lebih fokus dalam belajar, menghafal, dan bermurojaah. Namun tidak demikian dengan pondok pesantren Raudlotul Qur'an Mangkangkulon hampir setiap santrinya dilatih memiliki jiwa enterpreneurship sehingga bisa hidup mandiri dan kreatif ditengah-tengah masyarakat.Hal ini sesuai dengan penuturan Nur Syam yang dikutip oleh Saeful Anam (2016) menyatakan bahwa "pada saat ini sedang gencar berlangsung transformasi pesantren. Pesantren tidak hanya untuk tempat belajar agama, tetapi juga untuk pendidikan umum dan kewirausahaan (entrepreneurship). Dengan adanya transformasi tersebut, alumni pesantren (output) nantinya tidak hanya menjadi guru agama ataupun guru mengaji saja, melainkan mereka dapat menduduki posisi strategis di berbagai bidang kemasyarakatan termasuk politik, ekonomi ataupun kepemerintahanan".

Tidak semua lulusan atau alumni pondok pesantren akan menjadi ulama' atau kyai sehingga perlu memilih pekerjaan sesuai dengan tuntunan agama islam. Santri perlu diberi pelatihan keterampilan sebagai bekal ketika lulus dari pesantren. Menurut Muttaqin (2011), membangun watak dan jiwa santri melalui kegiatan pendidikan berarti berusaha mengembangkan seluruh potensi yang ada pada santri, lalu dikembangkan secara optimal dalam batas hakekat masingmasing sehingga setelah mengikuti kegiatan pendidikan, mereka akan menjadi manusia yang memiliki karakter dan mandiri. Maka pendidikan di pondok pesantren Raudlotul Qur'an dituntut untuk mampu merealisasikan tujuan pendidikan demi mewujudkan santri yang berwatak dan berjiwa mandiri agar mampu hidup mandiri di tengah-tengah masyarakat yang semakin berkembang.

$\mathrm{KH}$ Thohir Abdulloh Al Hafidz sebagai pengasuh pondok berasumsi bahwa kaum sarungan itu harus maju tidak boleh terpinggirkan, harus bisa 
bersaing dan bersanding dengan masyarakat.Pendidikan yang ditujukan pada santri tidak saja terbatas pada pendidikan agama serta pendidikan formal, namun juga pada pengembangan jiwa kewirausahaan.Pemberian bekal keterampilan dalam berwirausaha pada santri diharapkan mampu membentuk santri yang tangguh dalam menghadapi persaingan setelah lepas dari pondok pesantren.Sungguh ironis ketika santri lulus, mampu menguasai kitab-kitab kuning namun tidak mampu mengaplikasikan Qur'an dan Hadist secara benar di masyarakat.Para lulusan semakin jauh dan asing dari realitas masyarakat yang dihadapinya.Kondisi tersebut justru memberikan dampak negatif bagi pesantren dan telah keluar dari awal para ulama' perintisnya.Terlebih saat ini persaingan kerja yang sangat ketat menuntut alumni pondok pesantren untuk dapat mandiri dan berwirausaha. Alumni yang mandiri dan cakap berwirausaha akan diperoleh jika dalam pelaksanaan usaha, pihak pondok pesantren melibatkan santri terutama sebagai sarana pelatihan teknis bagi santri.

Hoerniasih (2017) dalam seminar nasional pendidikan nonformal menyampaikan bahwa Ajaran islam tidak memisahkan antara iman dan amal shaleh. Karena itu ajaran Islam berisi ajaran tentang sikap dan tingkah laku pribadi masyarakat menuju kesejahteraan hidup perorangan dan bersama. Ajaran Islam menekankan keseimbangan hidup baik jasmani maupun rohani sebagai satu kesatuan tanpa mengesampingkan salah satu aspek yang lain. Oleh sebab itu, ajaran Islam sangat relevan untuk mengembangkan sikap kewirausahaan (enterpreneur) pada umatnya untuk meningkatkan kesejahteraan hidupnya.

Pondok pesantren seyogyanya tidak semata-mata sebagai lembaga pendidikan yang mengajarkan serta menyebarkan ilmu agama islam untuk santrinya, melainkan juga lembaga yang mampu mengayomi masyarakat sekitar serta dapat menggerakkan roda-roda perekonomian masyarakat sekitarnya. Pondok Pesantren mempunyai akar sosio-historis yang cukup kuat di masyarakat, sehingga tetap mampu bertahan di tengah gelombang perubahan bahkan mampu menduduki posisi sentral dalam dunia keilmuwan masyarakat (Ibrahim: 2016).

Pondok pesantren diharapkan mampu mencetak para santrinya untuk bisa hidup mandiri dan kreatif melalui enterpreneur. Menurut Ghofirin dan Karimah (2017) jiwa enterpreneur ditunjukkan melalui sifat dan watak berwirausaha dalam mewujudkan gagasan inovatif menjadi kreatif yang ditanamkan di pondok pesantren kepada para santri. Santri dikenal mempunyai karakter mandiri, sederhana, tidak mudah menyerah serta berani mengambil resiko. Karakter santri demikianlah yang menjadi modal berjiwa enterpreneurship. Santri dituntut untuk pandai mengalokasikan hidupnya di pesantren dengan berwirausaha kecil- 
kecilan, yang tentunya tidak perlu repot-repot menghabiskan banyak waktu. Hal ini adalah untuk menambah pemasukan uang kas pesantren serta memberikan bekal pengalaman kepada santri agar nantinya dapat diterapkan di rumah setelah lulus dari pesantren.

Pada bulan Desember 2015, Pemerintah memberlakukan adanya Kebijakan Masyarakat Ekonomi Asean (MEA), kebijakan tersebut menghadirkan sebuah tantangan baru bagi masyarakat untuk bertindak ekonomis dan berusaha meningkatkan skill untuk menciptakan tingkat daya saing yang tinggi. Masyarakat tidak hanya disiapkan untuk bisa bekerja namun harus mampu mempersiapkan dan membuka lapangan kerja baru. Realitas yang terjadi selama ini, bahwa masyarakat dididik untuk menjadi para pencari kerja. Pekerjaan setiap tahun bertambah sedangkan lapangan pekerjaan yang tersedia tidak mencukupi. Akibatnya, setiap tahun jumlah pengangguran terus meningkat. Hal ini dibuktikan dengan ramainya bursa lowongan kerja yang dipenuhi oleh para pencari kerja.

Dari uraian di atas, pondok pesantren juga harus ikut mempersiapkan santri-santrinya untuk bisa mempersiapkan diri menghadapi MEA. Nadzir (2015) menyatakan pondok pesantren dapat berperan sebagai lembaga perantara yang diharapkan dapat menjadi dinamisator dan katalisator pemberdayaan sumberdaya manusia, penggerak pembangunan di segala bidang, termasuk di bidang ekonomi.Sistem ekonomi kreatif melalui kegiatan berwirausaha diyakini mampu menjadi solusi dalam mengatasi masalah tersebut.

\section{SEJARAH PESANTREN}

Cikal bakal Pesantren Raudlatul Qur'an kali pertama dirintis oleh KH Muhlasin Muhdlor sebagai respon atas permintaan masyarakat saat itu yang antusias berkeinginan memperdalam ilmu agama. Secara ringkas fase perkembangan pesantren ini dapat di pilah menjadi dua kurun spasi sejarah.

Pertama, Fase rintisan; Transmisi Khasanah klasik. Tahun 1986 menandai awal berdirinya meskipun dengan banyak keterbatasan akan tetapi anasir suatu lembaga di katakan sebagai pesantren telah terpenuhi yakni kyai, santri,asrama dan kegiatan pengajaran kitab klasik. Hingga medio 2002 merupakan fase rintisan dimana $\mathrm{KH}$ Muhlasin Muhdlor menjalankan kegiatan belajar mengajar santri mengikuti format pendidikan lazimnya di pesantren tradisional pada umumnya. Dimana pesantren dan kyai membatasi diri berkonsentrasi pada proses transmisi keilmuan. Orientasi tradisi demikian berlangsung kurang lebih selama 11 tahun hingga tahun 2002.Sebagaimana dikemukakan Ziemek, pesantren mengalami masa statis.Artinya tidak ditemukan kemajuan-kemajuan 
yang berarti.Belum ditemukan pembaruan-pembaruan makna baru peran pesantren selain sebagai great tradition, meminjam istilah Martin Van Bruinesen. Pada kurun ini Pesantren Raudlatul Qur'an masih konsisten mengukuhkan diri sebagai pusat transfer of knowledge keilmuan klasik ala pesantren salaf yakni pengajaran kitab kuning dan pengajaran Al quran. Hal ini dikarenakan kyai merupakan figur sentral yang banyak berpengaruh memberikan warna dan arah haluan pesantren. Kondisi seperti ini dapat di mengerti mengingat keterbatasan sumberdaya pesantren kala itu.Terkecuali itu faktor background tingkat pendidikan santri didik yang belum sepenuhnya siap merespon gagasan-gagasan akan kemajuan pesantren. Pada fase ini secara sederhana pesantren berorientasi pada upaya melestarikan khazanah keilmuan klasik (salaf), transfer wawasan keagamaan yang mumpuni ( tafaqquh fid ad din) serta menyiapkan eksponen dakwah dimasyarakat. Tegasnya output yang diharapkan adalah ulama pelestari tradisi dan reproduksi kader dakwah yang puritan (Ahsan: 2004).

Fase kedua Tahun 2002 - sekarang ; menuju optimalisasi peran. Mengukuhkan tesis penulisan Ziemek bahwa setelah Tahun 1970-an mulai menampakkan adanya perubahan-perubahan berarti di lingkungan pesantren. Demikian halnya pada fase kedua di mulai pada tahun 2002 hingga sekarang tepatnya generasi kedua setelah estafet kepemimpinan dipegang oleh putra sulung KH Muhlasin Muhdlor yakni KH Thohir Abdulloh Al Hafidz ditengarai adanya perubahan ke arah pengembangan pesantren. Pada fase ini dari aspek kependidikan pesantren mulai menitikberatkan pada pembelajaran dan pengajaran Al-Qur'an yang berlangsung secara gradual dari baca tulis (resitation, writting), penghafalan (tahafudy) serta pendalaman kajian pemahaman (tafsir dan hukum). Pengajaran dan pembelajaran bagi santri sudah mulai tersistemasi melalui kelembagaan (sistem madrasi) mengikuti tren pendidikan formal dengan sistem klasikalnya. Diluar sistem pendidikan KH Thohir Abdullah Al Hafidz mencanangkan pelbagai kegiatan ektra kurikuler termasuk di antaranya kegiatan ekonomi. Mempertimbangkan bahwa pesantren bertanggungjawab melahirkan para lulusan (mutakhorrijin) yang tidak saja berwawasan agama kuat namun juga siap bermasyarakat dan berkemandirian secara ekonomi. Maka kemudian pengasuh menginisiasi dan mendorong terlaksananya kegiatan ekonomi pesantren. Penambahan komplementer dari semula orientasi tunggal transfer keilmuan klasik dengan kegiatan ekonomi berproses secara dialektis. Pengasuh tidak lagi memposisikan sebagai patron yang determinatif dan di pihak lain santri sebagai client yang sub ordinatif. Terbukti dalam penerimaan ide usaha ekonomi hingga manajemen realisasinya terkadang bersifat top down dari kyai pengasuh namun juga bottom up dari santri ke kyai pengasuh. Meski kyai tetap memegang 
peran sentral sebagai kontrol dan pemegang keputusan akhir (policy and decision maker). Hal demikian banyak dipengaruhi oleh wawasan dan pola pemikiran yang cenderung terbuka (open mind) pada gilirannya membawa pengaruh pada pola kepemimpinan kyai pengasuh. Pengaruhnya berlanjut pada sistem dan manajemen pesantren itu sendiri mengarah pada modernitas pesantren sebagaimana kemudian banyak ditemukan pada pesantren mutakhir. Walhasil ide pemberdayaan santri melalui kegiatan pembinaan enterpreneurship menemukan ruang untuk terus berlanjut di Pesantren Raudlotul Qur'an Mangkang. Dengan demikian dapat disimpulkan bahwa terjadi haluan, serta visi misi pesantren dengan capaian tidak sekedar mencetak kader dakwah maupun reproduksi ulama ansich namun out put santri didik kedepan menjadi kader muslim yang berjiwa kemandirian dalam ekonomi.

\section{GAMBARAN UMUM PONDOK PESANTREN RAUDLOTUL QUR'AN MANGKANG}

Pondok Pesantren Raudlotul Qur'an berada di kelurahan Mangkang Kulon, Kecamatan Tugu, Kota Semarang Provinsi Jawa Tengah.Pondok pesantren didirikan pada tanggal 14 Agustus 1994 oleh KH.Thohir Abdullah, AH.KH yang sekaligus menjadi pengasuhnya sampai saat ini.Gedung pondok pesantren Raudlotul Qur'an berdiri diatas tanah seluas $40 \mathrm{~m}$ x $50 \mathrm{~m}=2.000 \mathrm{~m}^{2}$.

Pondok pesatren Raudlotul Qur'an merupakan salah satu pesantren yang rintisan awalnya dari sebuah majelis ta'lim atau pengajian ibu-ibu.Namun, majelis ta'lim tersebut lambat laun ditempati santri yang ingin menuntut ilmu agama.Setelah itu, Ponpes melakukan pengembangan dengan menambah kamarkamar, aula dan beberapa fasilitas untuk keperluan santri. Jumlah santri dan santriwati adalah 170 dari berbagai kota. Para santri mayoritas adalah pelajar dan mahasiswa namun juga tidak sedikit adalah santri tulen. Santri tulen mayoritas adalah para santri tahfidzul qur'an sembari untuk menghatamkan hafalannya. Dari riwayat historis, Ponpes Raudlotul Qur'an memang erat sekali hubungannya dengan masyarakat. Di tengah-tengah kegiatan ngaji seperti layaknya pondok salaf pada umumnya, disini para santri dilatih untuk bisa hidup mandiri dan kreatif.

Tuntutan perkembangan zaman menjadikan pondok pesantren agar memiliki kemandirian ekonomi. Pondok pesantren Raudlotul Qur'an mengadakan kegiatan kewirausahaan untuk mengembangkan ekonomi pesantren dan melatih santri untuk berwirausaha dengan mendirikan toko sembako dan alat tulis, warung es degan, koperasi pondok, pertamini, peternakan kambing, warnet, kost makan yang dikelola oleh santri sendiri. Dengan melaksanakan 
kegiatan kewirausahaan di pondok pesantren, berarti para santri telah berlatih diri menjadi wirausahawan, sebagai bekal kelak untuk usaha mandiri ketika telah lulus belajar dipondok pesantren.

Setiap pondok pesantren akan berbeda bidang kegiatan kewirausahaannya, sesuai dengan kondisi dan potensi. Cara pengelolaan usahanya pun sangat beragam. Sebagian pondok pesantren banyak melibatkan para santri senior, santri karyawan, mungkin pula hanya sedikit melibatkan para santri. Dalam hal ini para santri minimal bisa belajar, mengamati dan latihan berwirausaha. Ketika lulus dan keluar dari pondok pesantren, telah tergambar dalam benaknya, bidang usaha apa yang potensial untuk dapat dikembangkan disamping terus melaksanakan dakwah sebagai tugas pokoknya. Pengelolaan usaha pondok pesantren Raudlotul Qur'an dilakukan oleh santri. Setiap santri dijadwal untuk bisa bertukar jaga dengan sistem piket harian tentunya dengan ada penanggung jawab pokoknya. Dari beberapa fasilitas di atas, pesantren telah berusaha untuk menumbuhkan jiwa enterpreneur pada masing-masing santri.

\section{PENGEMBANGAN JIWA ENTERPRENEURSHIP SANTRI MELALUI EKONOMI KREATIF}

Ekonomi kreatif menjadikan sumber daya manusia (SDM) sebagai modal utama dalam sebuah pengembangan yang berawal dari gagasan, ide dan pemikiran. SDM ini diharapkan mampu menjadikan barang yang bernilai rendah menjadi barang yang bernilai tinggi dan berdaya jual (Novianti: 2017). Demikian juga Pahlevi (2017) mengatakan ekonomi kreatif dikenal sebagai konsep pengembangan ekonomi yang mengandalkan daya kreasi untuk menciptakan produk maupun menambah nilai/value. Nilai ekonomi dari produk tidak lagi ditentukan oleh bahan baku atau mutu produk melainkan ditentukan oleh kreativitas, inovasi dan imajinasi. Menurut Purnomo (2016) Ekonomi kreatif menjadi salah satu konsep untuk pengembangan perekonomian di Indonesia.Yang mana, Indonesia bisa mengembangkan model ide dan talenta dari rakyat untuk dapat menginovasi dan menciptakan suatu hal. Pola pikir kreatif yang sangat diperlukan untuk tetap tumbuh berkembang serta bertahan di masa yang akan datang.

Saat ini ekonomi kreatif memiliki potensi besar untuk menjadi salah satu sektor penggerak roda perekonomian nasional.Seiring perkembangan teknologi dan mudahnya akses wawasan kewirausahaan kreatif, produk-produk kreatif mulai banyak bermunculan. Peluang pengembangan ekonomi kreatif telah merambah pada dunia pendidikan, tidak terkecuali pada dunia pesantren. Berdasarkan hasil penulisan studi kasus Noviyanti (2017) di lingkungan pondok 
modern Gontor telah banyak mengembangkan industri ekonomi kreatif diantaranya adalah dalam sektor video, film dan fotografi, kuliner, fesyen, musik, kerajinan, penerbitan dan percetakan, seni rupa dan seni pertunjukan. Dalam hal ini, pesantren yang identik dengan ruh pendidikan Islam, kini telah berkembang mengikuti arus kontemporer dalam memberdayakan santri-santrinya.

Pondok pesantren Raudlotul Qur'an berusaha untuk melatih santrisantrinya agar mandiri dan kreatif.Melalui beberapa bidang usaha yang dimiliki oleh pondok pesantren santri mampu mengelola waktu untuk melaksanakan kewajiban untuk mengaji tanpa meninggalkan mengabdi. Dalam mengelola bidang usaha yang dimiliki oleh pondok pesantren tentunya para santri mulai memiliki jiwa enterpreneurship. Jiwa enterpreneurship yang telah dimiliki oleh santri perlu dikembangkan sehingga santri mampu mengatasi permasalahanpermasalahan yang muncul dalam berwirausaha. Untuk mngembangkan jiwa enterpreneurship santri perlu dilakukan pendampingan berupa pendampingan usaha ekonomi kreatif.

Koperasi pondok pesantren menyediakan kebutuhan sehari-hari santri termasuk jajanan. Penulis melihat banyak limbah-limbah plastik bungkus jajanan maupun minuman belum dikelola secara optimal. Begitu pula di bidang usaha warung es degan, masih terlihat gunungan sabut dan tempurung kelapa di belakang warung, peternakan kambing menyisakan kotoran kambing yang dibiarkan begitu saja, limbah bahan makanan seperti sayuran busuk, kulit pisang dll juga ditemukan di area pondok pesantren. Keterbatasan pemikiran santri menjadikan bidang usaha belum optimal jika dilihat secara keseluruhan.Ada beberapa hal yang menimbulkan beberapa problematika terhadap lingkungan sekitar. Penulis melihat perlu adanya pendampingan dalam kegiatan-kegiatan usaha tersebut. Dari banyaknya permasalahan yang dihadapi pondok pesantren, penulis berusaha memberikan solusi pemecahan masalahnya melalui usaha ekonomi kreatif.

Pendampingan usaha ekonomi kreatif di pondok pesantren Raudlotul Qur'an memiliki tujuan untuk mengembangkan pemikiran santri bahwasannya limbah-limbah plastik jajanan dan minuman, sabut dan tempurung kelapa, serta sisa-sisa makanan termasuk kulit pisang dapat bernilai ekonomi jika diolah. Pendampingan usaha ekonomi kreatif yang dilakukan di pondok pesantren Raudlotul Qur'an antara lain; pertama, Virgin Coconut Oil (VCO). Pondok pesantren Raudlotul Qur'andalam usahanya membangun warung es degan cukup memberikan pemasukan finansial yang berarti.Berdasarkan wawancara dengan salah satu santri pengelola, Muniruddin mengatakan bahwa dalam 1 hari, bisa menghabiskan 50 kelapa muda. Dari sekian banyaknya kelapa muda yang 
dipakai, tidak sedikit juga terkadang mendapatkan kelapa tua. Selama ini jika memperoleh kelapa tua maka kelapa akan dimanfaatkan oleh santri untuk keperluan masak harian diambil santannya, lauk botok teri atau diolah menjadi 'rondo royal' atau gorengan kelapa dicampur dengan tepung terigu dan gula.

Menurut hasil analisa, sebenarnya kelapa tua atau setengah tua tersebut dapat dimanfaatkan lebih dari itu. Kelapa tersebut dapat diolah menjadi Virgin Coconut Oil (VCO). VCO adalah minyak murni yang dibuat dari bahan baku kelapa segar tanpa menggunakan bahan kimia apapun dengan melalui berbagai macam proses, contohnya melalui fermentasi dan pemanasan. Proses pembuatan yang tepat akan menghasilkan minyak VCO yang berkualitas. Keunggulan dari minyak ini adalah jernih, kadar air dan kadar asam lemak bebas yang rendah, berbau harum, tidak mudah tengik dan tahan hingga 12 bulan. Pembuatan VCO ini memiliki banyak keunggulan yaitu tidak membutuhkan biaya mahal karena bahan baku mudah didapat dengan harga murah, pengolahan sederhana dan tidak terlalu rumit serta menggunakan energi minimal karena tidak banyak menggunakan bahan bakar sehingga kandungan kimia dan nutrisinya tetap terjaga (Widiyanti: 2015).

Minyak VCO memiliki sebutan bermacam-macam. Masyarakat umum ada yang menyebut minyak murni, minyak perawan minyak kelapa murni bahkan ada yang menyebut minyak ajaib.Dilihat dari manfaatnya yang sangat banyak memang pantas bila minyak ini disebut sebagai minyak ajaib. Hal ini senada dengan hasil penulisan dari Widiyanti (2015) yang menyimpulkan bahwa VCO memiliki beberapa keunggulan yaitu kandungan asam laurat yang tinggi. Asam laurat di dalam tubuh akan diubah menjadi monolaurin yaitu sebuah senyawa monogliserida bersifat antibiotik diantaranya sebagai antivirus, antibakteri, antiprotozoa sehingga dapat meningkatkan daya tahan tubuh manusia terhadap penyakit serta mempercepat proses penyembuhan. Dilihat dari segi produksi maupun harga jual yang tinggi, VCO merupakan potensi unggulan yang perlu dikembangkan (Maradesa, dkk: 2014). Oleh karena itu, penulis memberikan saran kepada para santri untuk memanfaatkan kelapa tua segar tersebut untuk diolah menjadi VCO yang kaya akan manfaatnya.

Kedua, BrownCanKupang (Brownies Cantik Kulit Pisang). Buah pisang merupakan buah yang sangat bermanfaat bagi kehidupan manusia, yang dapat dikonsumsi kapan saja dan pada segala tingkatan usia. Pisang dapat digunakan sebagai alternatif pangan pokok karena mengandung karbohidrat yang tinggi, sehingga dapat menggantikan sebagian konsumsi beras dan terigu (Prabawati, dkk: 2008). 
Menurut Rismunandar dalam Wahyuni (2010) selain buahnya, tanaman ini juga dapat dimanfaatkan dari bonggol hingga daunnya. Bonggol tanaman pisang dan batang muda dapat diolah menjadi sayuran. Bunga pisang (jantung pisang) dapat digunakan untuk sayur, manisan, acar maupun lalapan.Daunnya dapat memberikan rasa harum spesifik pada nasi atau jajanan yang dibungkus dalam keadaan panas. Buah pisang mentah dapat diolah menjadi gaplek, tepung, pati, sirup, tape dan keripik.Buah pisang matang dapat diolah menjadi menjadi sale, selai, dodol, sari buah dll. Sedangkan untuk kulit pisang, sebagian besar masyarakat jarang sekali untuk memanfaatkannya secara nyata.

Berdasarkan pengamatan penulis, bahwa setiap pagi hari ibu pengasuh ponpes beserta dengan beberapa santriwati menyediakan sarapan bagi santrisantri terutama bagi mereka yang hendak berangkat ke sekolah. Sarapan pagi seperti rames, teh anget dan beberapa gorengan seperti mendoan, tahu isi dan pisang goreng. Dari sini ditemukan adanya limbah dari kulit pisang setiap harinya, padahal menurut Balai Penulisan dan Pengembangan Industri (1982) dalam Mulyo, dkk. (2014) bahwa kulit pisang memiliki kandungan air 68,9 g, KH 18,5 g, Protein 0,32 g, Lemak 2,11 g, kalsium $715 \mathrm{mg}$, fosfor $117 \mathrm{mg}$, besi 1,6 $\mathrm{mg}$, vitamin B 0,12 mg, dan vitamin C 17,5 mg. Hal senada juga disampaikan oleh Arifah (2016)Berdasarkan artikel tahun 2011 dalam Applied Biochemistry and Biotechnology dikatakan bahwa dalam kulit pisang mengandung antioksidan seperti karotenoid dan polifenol. Senyawa ini dikenal baik untuk cegah diabetes, serangan jantung dan kanker.

Dari data di atas, terlihat bahwa limbah kulit pisang mengandung zat gizi yang cukup tinggi terutama vitamin dan mineralnya sehingga sayang sekali jika dibuang begitu saja melainkan dapat dimanfaatkan sebagai bahan baku makanan. Salah satunya adalah dengan membuat brownies dari kulit pisang.

Ketiga, Arang Batok Kelapa. Ponpes Raudlotul Qur'an telah melatih para santrinya untuk berwirausaha dengan berjualan mendirikan warung es degan. Ketika musim panas, dalam satu hari mampu menghabiskan 50-60 buah kelapa muda.Dari hasil usaha tersebut mendatangkan permasalahan baru yaitu adanya limbah dari tempurung kelapa. Menurut pengamatan, tempurung-tempurung itu hanya ditumpuk di belakang toko. Dari pihak pesantren ternyata sempat memanfaatkan tempurung itu untuk digunakan sebagai bahan bakar memasak dengan cara dijemur dulu dibawah terik matahari. Mengingat perubahan cuaca yang tidak menentu, membuat pemanfaatan tersebut tidak lagi diteruskan.Arang batok kelapa merupakan produk yang didapatkan dari sebuah pembakaran batok kelapa yang tidak sempurna.Arang batok kelapa bila digunakan sebagai bahan bakar ternyata lebih efisien dibandingkan dengan kayu bakar. Hal ini 
dikarenakan arang dapat menghasilkan panas lebih baik dengan sedikit asap. Arang merupakan salah satu alternatif bahan bakar yang cukup menjanjikan untuk subtitusi minyak tanah (Purwanto: 2011). Oleh sebab itu, maka perlu adanya pendampingan untuk membuat arang batok kelapa dengan cara lain.

Keempat, Kreasi Tas dan Dompet dari Bungkus Marimas. Sampah merupakan suatu bahan yang terbuang begitu saja dari hasil aktivitas manusia dan dianggap tidak mempunyai nilai ekonomi.Sampah terbagi menjadi dua yaitu sampah organik (mudah terurai) dan anorganik (sulit terurai).Sampah plastik merupakan sampah yang paling banyak ditemui dalam kehidupan seharihari.Plastik mudah terbakar, sehingga megakibatkan ancaman terjadinya kebakaranpun meningkat.Sampah plastik merupakan sampah anorganik.Apabila tertimbun di dalam tanah, butuh waktu berjuta-juta tahun untuk mengurainya. Hal ini senada dengan yang disampaikan oleh purwaningrum (2016) bahwa sifat plastik akan terurai di tanah dalam waktu lebih dari 20 tahun bahkan dapat mencapai 100 tahun sehingga dapat menurunkan kesuburan tanah dan di perairan plastik akan sulit terurai.

Asap hasil pembakaran bahan plastik sangat berbahaya karena mengandung gas-gas beracun seperti hidrogen sianida ( $\mathrm{HCN})$ dan karbon monoksida (CO). Hidrogen sianida berasal dari polimer berbahan dasar akrilonitril, sedangkan karbon monoksida sebagai hasil pembakar tidak sempurna.Hal inilah yang menyebabkan sampah plastik sebagai salah satu penyebab pencemaran udara dan mengakibatkan efek jangka panjang berupa pemanasan global pada atmosfer bumi. Selain itu, Pembuangan sampah plastik sembarangan di sungai-sungai akan mengakibatkan pendangkalan sungai dan penyumbatan aliran sungai sehingga menyebabkan banjir.

Berdasarkan pengamatan bahwa sampah hasil penjualan minuman kemasan seperti marimas sangat banyak ditemui di tempat sampah koperasi ponpes.Hal ini membuat ironi jika sampah plastik tersebut hanya dibuang begitu saja, mengingat lokasi ponpes yang sering terkena banjir hampir setahun sekali. Jika sampah plastik tersebut dibuang begitu saja maka akan memperparah dampak buruk dari pembuangan sampah tersebut.

Sampah plastik yang sudah tidak terpakai ini dapat dimanfaatkan sebagai kreasi seni yang tinggi apabila kita mampu mengolahnya. Salah satu pemanfaatannya adalah dengan membuat tas dan dompet dari bungkus minuman seperti marimas. Pembuatan tas dan dompet dari limbah plastik merupakan suatu bentuk usaha ekonomi kreatif agar sampah yang tidak berguna dapat mempunyai nilai ekonomis. 


\section{METODE PENDAMPINGAN}

Dalam pelaksanaan program pendampingan ini, tim pendamping telah melakukan penyusunan rencana metode yang akan dilakukan selama proses awal sosialisasi dan rencana selama kegiatan berlangsung. Adapun dalam sosialisasi awal, tim pendamping terlebih dahulu mengundang para santri dan santriwati Ponpes Raudlotul Qur'an untuk mensosialisasikan kegiatan yang akan dilangsungkan. Dalam sosialisasi awal, tim pendamping memiliki tujuan agar terjadi komunikasi timbal balik tentang bagaimana cara yang efektif untuk mengajak para santri ikut serta dalam kegiatan ini.

Tabel 1. Tabel metodologi pelaksanaan kegiatan

\begin{tabular}{|c|c|c|c|}
\hline Materi & Metode & Evaluasi & $\begin{array}{l}\text { Alokasi } \\
\text { Waktu }\end{array}$ \\
\hline $\begin{array}{l}\text { Pelatihan pembuatan } \\
\text { VCO }\end{array}$ & $\begin{array}{l}\text { Ceramah dan } \\
\text { praktik }\end{array}$ & Tanya Jawab & $1 \times 60$ menit \\
\hline $\begin{array}{l}\text { Pelatihan pembuatan } \\
\text { BrownCanKupang }\end{array}$ & $\begin{array}{l}\text { Ceramah dan } \\
\text { praktik }\end{array}$ & Tanya Jawab & $1 \times 60$ menit \\
\hline $\begin{array}{l}\text { Pelatihan pembuatan } \\
\text { Arang Batok Kelapa }\end{array}$ & $\begin{array}{l}\text { Ceramah dan } \\
\text { praktik }\end{array}$ & Tanya Jawab & $1 \times 60$ menit \\
\hline $\begin{array}{l}\text { Pelatihan pembuatan } \\
\text { Kreasi Tas dan } \\
\text { Dompet dari Bungkus } \\
\text { Marimas }\end{array}$ & $\begin{array}{l}\text { Ceramah dan } \\
\text { praktik }\end{array}$ & Tanya Jawab & $1 \times 60$ menit \\
\hline
\end{tabular}

Pada waktu kegiatan pelatihan, metode yang digunakan adalah Metode Trainning of Trainner (TOT) dengan cara pemberian materi melalui ceramah, kemudian dilanjutkan dengan praktik langsung oleh masing-masing peserta. Tim pendamping tidak mengundang seluruh santri, tapi hanya pengurus ponpes. Pengurus santri putri 15 orang dan pengurus santri putra 10 orang.

Hal ini dimaksudkan agara perwakilan tersebut selanjutnya dapat melatih para santri yang lain untuk membentuk tim kerja. Cara tersebut dianggap lebih efektif karena transfer pengetahuan yang diperoleh selama pelatihan akan lebih tersampaikan dengan baik jika peserta pelatihan itu sendiri yang menyampaikannya dan merasa bahwa kegiatan pelatihan tersebut bermanfaat bagi mereka.

\section{HASIL PENDAMPINGAN DAN PEMBAHASAN}

Santri Ponpes Raudlotul Qur'an berjumlah 170 orang dengan rincian santri Putra 40 orang dan santri putri 130 orang. Berdasarkan hal ini, tim pendamping 
tidak mengundang seluruh santri, namun hanya mengundang para pengurusnya saja. Pengurus putra 5 orang dan pengurus putri 15 orang.Pada awal pelatihan sistem pelatihan yang digunakan adalah TOT (Trainning of Trainer).

Selama kegiatan berlangsung tim pendamping melakukan usaha untuk mengefektifkan waktu agar kegiatan berjalan dengan lancar. Secara singkat dapat dikatakan bahwa pelatihan dilakukan secara berurutan dalam waktu bersamaan pada hari sabtu (6 Januari 2018) di Pondok pesantren Raudlotul Qur'an.

Dalam kegiatan pelatihan ini, tim pendamping membagi kader pengurus menjadi 4 kelompok. Masing-masing kelompok terdiri dari 5 santri. Tujuan dari pengelompokan ini adalah agar kinerja mereka lebih mudah jika dilakukan dengan anggota yang sudah dikenal dengan baik, selain itu diharapkan agar jika nantinya mereka akan menumbuhn kembangkan usaha ini di desa mereka masing-masing, mereka dapat mengelolanya dengan mudah. Instrumen pelaksanaan masing-masing kelompok tersebut diberikan sama poroporsinya, sehingga memudahkan mereka untuk melakukan kegiatan. Setiap peserta pelatihan juga diharuskan untuk mengaplikasikan materi yang sudah diberikan tim pendamping, jadi tidak ada santri yang tidak ikut terlibat.

Beberapa tahapan yang dilakukan oleh santri untuk memproduksi masingmasing produk yaitu VCO, arang, browncankupang, kreasi dompet dan tas dari bungkus marimas. Untuk membuat Virgin Coconut Oil (VCO), alat yang dibutuhkan diantaranya; Baskom bersih, Parutan kelapa, Wajan bersih, Gelas, Botol yang sudah disterilan, Serbet bersih, Saringan santan, 1 buah kelapa tua, dan $500 \mathrm{ml}$ air. Peserta ToT mempraktekkan produksi VCO secara berurutan. Kupas buah kelapa yang telah disiapkan kemudian parut. Kelapa dibuat santan dengan mencampurkan parutan dari 1 buah kelapa tua dengan $500 \mathrm{ml}$ air. Santan dipanaskan di atas api kecil, wajan yang digunakan untuk memanaskan santan sebaiknya tidak ada bekas bau masakan lain, supaya aroma minyak yang dibuat tidak terpengaruh. Setelah mendidih, antan akan terbagi menjadi tiga lapisan. Lapisan pertama disebut kanil, lapisan kedua disebut skim, ketiga baru air. Lapisan paling atas yang berupa krim diambil dengan cara disendok supaya tidak tercampur dengan lapisan kedua. Selanjutnya kanil tersebut dipanskan supaya terbentuk minyak. Gunakan api kecil dan aduk perlahan-lahan supaya tidak hangus dan benda tidak menjadi berwarna kecoklatan atau gosong. Hentikan pemanasan jika telah terjadi pemisahan benda dengan minyak, kemudian angkat dan dinginkan. Saring blondo dari minyak, kemudian pres blondo dengan kain serbet bersih agar semua minyak keluar. Semua minyak yang diperoleh ini masih berupa minyak mentah. Panaskan kembali minyak hingga didapat minyak yang lebih jernih. Terakhir, dinginkan, dan kemas dalam botol. 
Di waktu lain santri mempraktekkan membuat BrownCanKupang (Brownies Cantik Kulit Pisang). Santri dan tim menyiapkan alat dan bahan yang dibutuhkan, seperti; Pisau, Tempat cup roti, Pengukus, Talenan, Solet, Pengocok telur, Baskom, Blender, Sendok, Penggorengan, 10 Kulit pisang raja, $1 / 3 \mathrm{~kg}$ tepung terigu, 2 butir telur, Fermipan $1 \mathrm{sdm}, 150$ gr margarine, 1 gelas belimbing air matang, $1 / 2 \mathrm{~kg}$ gula pasir, 1/2 bungkus coklat batangan, 1 bungkus chocolatos/coklat bubuk, 2 bungkus susu Frisian flag coklat, dan Meses secukupnya.

Segenap santri mempraktekkan pembuatan BrownCanKupang melalui beberapa tahapan. Cuci kulit pisang kemudian kukus hingga kecoklatan, Blender kulit pisang yang sudah dikukus tambahkan dengan 1 gelasair matang. Cairkan margarin. Cairkan coklat batangan. Kocok telur hingga mengembang masukkan gula pasir, kocok kembali hingga larut. Masukkan tepung terigu, fermipan, coklat cair, margarin cair, kulit pisang halus. Olesi cup roti dengan margarin, masukkan adonan ke dalam cup lalu kukus hingga matang. Terakhir, Angkat dan hiasi dengan meses, sajikan.

Santri putra juga diajak mempraktekkan membuat Arang Batok Kelapa. Mereka menyiapkan alat dan bahan yang diperlukan, diantaranya; Drum bekas, Plat besi, Tanah liat, Paku, Palu, Korek api, dan Batok kelapa. Alat dan bahan yang ada dipakai untuk proses pembuatan. Siapkan drum bekas yang telah dilubangi bagian bawahnya sebanyak 8 buah lubang. Susunlah tempurung (batok) kelapa ke dalam drum tadi kira-kira 1/4 bagian. Kemudian arang dibakar sampai menyala. Setelah tempurung (batok) kelapa menyala semua, masukkan kembali tempurung (batok) kelapa 1/4 bagian lagi dan seterusnya hingga penuh. Setelah terbakar semua, kemudian tutup dengan plat besi yang dilapisi dengan tanah liat.

Terakhir, santri diajari membuat Kreasi Tas dan Dompet dari Bungkus Marimas. Alat dan Bahan yang dibutuhkan dan disiapkan santri antara lain; Gunting, Bungkus Marimas, Benang, dan Jarum. Proses pembuatannya meliputi; Siapkan satu bekas bungkus marimas. Potong menjadi dua bagian selebar $4 \mathrm{~cm}$. Potongan bekas bungkus marimas selebar $4 \mathrm{~cm}$ tersebut dilipat ke arah dalam sepanjang $1 \mathrm{~cm}$ dikedua sisinya sehingga menghasilkan pita plastik selebar $2 \mathrm{~cm}$. Buat pita seperti ini sebanyak minimal 250. Ambil 4 buah pita plastik dan anyam seperti membuat baling-baling untuk langkah awal. Pada baling-baling yang sudah terbentuk selanjutnya tambhkan pita lainnya satu persatu dan jangan lupa membuat sudut tegak vertikal agar bisa dianyam ke arah atas. Bila proses ini diabakan maka anyaman hanya akan terbentuk seperti tikar saja dan tidak berupa 
dompet atau tas. Atur lebar dan tinggi anyaman sesuai kebutuhan. Setelah dompet atau tas cantik selesai, siap digunakan.

Berikutnya, santri yang diikutkan dalam ToT diberi tugas untuk menularkan cara pembuatan beberapa kreasi di atas kepada santri-santri yang lain. Pada tahap penularan tersebut, tim pendamping hanya sebagai evaluator dan tidak terlibat langsung dalam pelaksanaannya.

\section{KESIMPULAN}

Berdasarkan penulisan dengan pendampingan usaha ekonomi kreatif dengan metode TOT, santri pengelola masing-masing bidang usaha mulai mengembangkan bidang usaha. Limbah-limbah yang semula dibiarkan tanpa dimanfaatkan melalui pengolahan sekarang menjadi bernilai.Hal tersebut menunjukkan jiwa enterpreneurship santri yang terbangun mulai berkembang setelah diadakannya pendampingan. Santri pengelola semakin kritis dengan keadaan lingkungan, dan berpikir bahwa suatu limbahpun dapat bernilai ekonomi, seperti kelapa tua yang terselipkan diantara degan-degan dapat diolah menjadi Virgin Coconut Oil (VCO), tempurung kelapa dijadikan bahan arang, limbah-limbah plastik bungkus jajanan dan minuman ringan menjadi tas, dan kulit pisangpun dapat dijadikan bahan pembuatan brownies.

\section{DAFTAR PUSTAKA}

Ahsa, M. Azmi. 2006. Pesantren Dan Pemberdayaaan Ekonomi Umat (Studi Ide dan Kebijakan Pendidikan di Pesantren Wirausaha-Agrobisnis Abdurrahman Bin Auf Wonosari Klaten). Tesis. Yogyakarta: UIN Sunan Kalijaga

Arifah, Novia. 2016. Brokupang (Brownies Kulit Pisang). [Online]. Tersedia: http:// novianarifah.blogspot.co.id/2016/08/brokupang-brownieskulit-pisang.html. yang diakses pada tanggal 20 Juni 2017

Anam, Saeful. 2016. Pesantren Entrepreneur dan Analisis Kurikulum Pesantren Mukmin Mandiri Waru Sidoarjo Dalam Pengembangan Dunia Usaha. Marâji: Jurnal Studi Keislaman Volume 2, Nomor 2, Maret 2016; 304-329

Bruinessen, Martin van. 1995. Kitab Kunig: Pesantren dan Tarekat dan Tradisi-Tradisi Islam di Indonesia. Bandung: Mizan 
Ghofirin, Mohammad. dan Karimah, Yunia Insanatul. 2017. Pengabdian Pada Masyarakat Pondok Pesantren Qomaruddin Desa Bungah Gresik Kewirausahaan Santri, Community Development Journal Vol. 1 No. 2 December 2017.

Hoerniasih, Nia, Penerapan Nilai-Nailai Agama Islam dalam Mengembangkan Pendidikan Kewirausahaan di Pondok Pesantren, Seminar nasional nonformal FKIP Universitas Bengkulu, Vol 1 Nomor 1, Juli 2017.

Ibrahim, Rustam. 2016. Pesantren dan Pengabdian Masyarakat: Studi kasus Pondok Pesantren Dawar Boyolali Jawa Tengah. Al-Tahrir, Vol. 16, No. 1 Mei 2016: 89-108

Khoiriyah, Rihlatul. Ali Imron, Ahmad Munif, Lathifah Munawaroh, 2017. Penguatan Kampung Santri untuk Pengembangan Masyarakat Sadar Hukum di Wilayah Mangkang Kota Semarang, Dimas: Jumal Pemikiran Agama Untuk Pemberdayaan Volume 17, Nomor 2, Nopember 2017

Maradesa, Riliani P. dkk. 2014. Kualitas Virgin Coconut Oil (VCO) Sebagai Minyak goreng yang dibuat dengan Metode Pengadukan dengan Adanya Penambahan Kemangi (Ocimum santctum L.). Jurnal MIPA UNSRAT ONLINE 3 (1): $44-48$

Mulyo, Riska Amelia. dkk. 2014. Pemanfaatan Limbah Kulit Pisang sebagai Donat Tinggi Kalsium untuk Meminimalisir Kasus Pencemaran Lingkungan Akibat Sampah di Indonesia. Bogor: IPB

Muttaqin, Rizal, 2011. Kemandirian Dan Pemberdayaan Ekonomi Berbasis Pesantren (Studi atas Peran Pondok Pesantren Al-Ittifaq Kecamatan Rancabali Kabupaten Bandung terhadap Kemandirian Eknomi Santri dan Pemberdayaan Ekonomi Masyarakat Sekitarnya), Jurnal Ekonomi Syariah Indonesia, Volume I, No. 2 Desember 2011

Nadzir, Mohammad, 2015, Membangun Pemberdayaan Ekonomi di Pesantren, Economica Volume 6/Edisi 1/Mei 2015

Noviyanti, Ririn. 2017, Peran Ekonomi Kreatif terhadap Pengembangan Jiwa Enterpreneurship di Lingkungan Pesantren: (Studi Kasus di Pondok Moddern Darussalam Gontor Putri 1), Jurnal Penulisan Ilmia Intaj (2017): 77-99 
Pahlevi, Andreas Syah. 2017. Gagasan Tentang Pengemabnagn Ekonomi Kreatif Nasional (Studi Pada Potensi, Peluang dan Tantangan Ekonomi Kreatif di Kota Malang). Seminar Nasional Seni dan Desain: Membangun Tradisi Inovasi Melalui Riset Berbasis Praktik Seni dan Desain. FBS Unesa.

Prabawati, Sulusi. dkk. 2008. Teknologi Pascapanen dan Teknik Pengolahan Buah Pisang, Balai Besar Penulisan dan Pengembangan Pascapanen Pertanian. Badan Penulisan dan Pengembangan Pertanian

Purnomo, Rochmat Aldy. 2016. Ekonomi Kreatif: Pilar Pembangunan Indonesia cet.1. Surakarta: Ziyad Visi Media.

Purwaningrum, Pramiati. 2016. Upaya Mengurangi Timbulan Sampah Plastik di Lingkungan. JTL. Vol. 8 No.2, Desember 2016, 141-147

Purwanto, Djoko. 2011. Arang dari Limbah Tempurung Kelapa Sawit (Elaeis guineensis Jacq). Jurnal Penulisan Hasil Hutan Vol. 29 No. 1, Maret 2011: $57-66$

Wahyuni Irma Laili, dkk, 2010. Pemanfaatan Kulit Buab Pisang Sebagai Bahan Pangan Alternatif Melalui Program Pelatihan Pembuatan Dodol Kulit Pisang, K,Ripik Pisang, Manisan Kulit Pisangdan Selai Kulit Pisang Di Desa Olak - Alen Kecamatan Selopuro Kabupaten Blitar. Malang:Universitas Negeri Malang

Widiyanti, Rahma Ayu. 2015. Pemanfaatan Kelapa Menjadi VCO (Virgin Coconut Oil) Sebagai Antibiotik Kesehatan dalam Upaya Mendukung Visi Indonesia Sehat 2015, Prosiding Seminar Nasional Pendidikan Biologi 2015: Peran Biologi dan pendidikan Biologi dalam menyiapkan Generasi Unggul dan Berdaya saing Global. FKIP Universitas Muhammadiyah Malang

Ziemek, Manfred. 1986. Pesantren dalam Perubahan Sosial, Jakarta: P3M 
Membangun Jiwa ...

Zuanita Adriyani dkk.

Halaman ini sengaja dikosongkan 